\title{
Investigation of Lineaments in the Mid-Black Arc Region Using Bouguer Gravity Data
}

\author{
Orta Karadeniz Yayındaki Çizgiselliklerin Bouguer Gravite Verileri Kullanılarak Incelenmesi
}

\author{
Abdurrahman Yasir PARLAK ${ }^{1}$ D, Ali ELMAS ${ }^{1} \mathbb{D}$ \\ ${ }^{1}$ Karadeniz Technical University, Department of Geophysical Engineering TR-61080 Trabzon, Turkey
}

Geliş (Received): 27 Nisan (April) 2021 / Düzeltme (Revised): 08 Temmuz (July) 2021 / Kabul (Accepted): 05 Ekim (October) 2021

\begin{abstract}
The gravity data used in this study were taken from the Earth Gravity Model (EGM08) to investigate the crustal structure in the mid-Black arc region. In this study, geological structure boundaries that offer differences in density were tried to determine in the mid-Black arc region. For this purpose, the possible geological structure limits at the basement levels were especially focused on. For this reason, horizontal gradient and tilt angle techniques were practiced to find possible geological structure limits using first vertical derivative data of the regional gravity data of the region. The soft-hard sediment, basement, Conrad and Moho interfaces have been determined using the radial mean amplitude spectrum of Bouguer data of study region. The topographies of these interfaces were also presented utilizing the Parker-Oldenburg algorithm. Depth values found by inversion calculations for soft-hard sediment, basement, Conrad and Moho interface topographies are changed as 0.7-3.5, 2.1-7.4, 9.1-14.2, and 35.1$42.5 \mathrm{~km}$, respectively. The linearities determined in the study were matched against to substantial faults of region. It has been observed that there is a qualitative relationship between the faults, ore deposit and earthquake epicenters in the region. The results of this practice were based on studies such as exploring the ore deposits and investigating the risks of earthquakes in the future.
\end{abstract}

Keywords: First Vertical Derivative, Mid-Black Arc Region, Horizontal Gradient, Tilt Angle, Lineament

\section{$\ddot{O} Z$}

Orta Karadeniz yay bölgesindeki kabuk yapısını incelemek için, bu çalışmada kullanılan gravite verileri, Dünya Gravite Modelinden (EGM08) alınmıştır. Bu çalışmada Orta Karadeniz bölgesinde yoğunluk farklllıkları sunan jeolojik yapı sınırları belirlenmeye çalışılmıştır. Bu amaçla, özellikle, temel kaya seviyelerindeki olası jeolojik yapı sınırlarına yoğunlaşılmışıtır. Bu nedenle, bölgenin bölgesel gravite verilerinin birinci düşey türev verileri kullanılarak olası yapı sınırlarını bulmak için yatay gradyan ve eğim açısı teknikleri uygulanmıştır. Yumuşaksert sediment, temel kaya, Conrad ve Moho arayüzleri, çalı̧̧ma bölgesinin Bouguer gravite verilerinin radyal ortalama genlik spektrumlarl kullanılarak belirlenmiştir. Bu arayüzlerin topografyaları da Parker-Oldenburg algoritması kullanılarak sunulmuştur. Yumuşak-sert sediman, temel kaya, Conrad ve Moho arayüzey topografyaları için, ters çözüm hesaplamalarıla bulunan derinlik değerleri sırasiyla, 0.7-3.5, 2.1-7.4, 9.1-14.2 ve 35.1-42.5 km arasında değişmektedir. Çalışmada belirlenen çizgisellikler, bölgenin önemli fayları ile eşleştirilmişstir. Bölgedeki faylar, maden yataklart ve deprem merkez üsleri arasında niteliksel bir ilişki olduğu görülmüştür. Bu uygulamanın sonuçları, maden yataklarının araştırılması ve gelecekte deprem risklerinin araştırılması gibi çalışmalara altık olacă̆l düşünülmektedir.

Anahtar kelimeler: Birinci Düşey Türev, Orta Karadeniz Bölgesi, Yatay Gradyan, Tilt Açısı, Çizgisellik 
Parlak, Elmas

\section{INTRODUCTION}

The mid-Black arc region is situated in western part of Eastern Pontides (Figure 1). According to the International Seismological Center (ISC), the region has experienced many eartquakes. The region has several fault zones one of them is North Anatolian Fault Zone (NAFZ) which lies in the Alpine-Himalaya zone. According to ISC, within the historical time period, region, have shaken as a result of occurrences of a number of seismic events (URL1, 2020). The study area is approximately 200 $\mathrm{km}$ south-north orientation and $300 \mathrm{~km}$ west-east orientation (Figures 1 and 2). The study area can be divided into three subregion as axial, southern and northern zones (Eyüboğlu et al., 2007; Figure 1). The mid-Black arc region is one of the great examples for well-maintained continental arcs in the Alpine-Himalayan mountain zone (e.g., Eyuboglu et al., 2007; 2011). The geodynamic evolvement of this region is still debate on the score of the lack of scientific data sets. A number of scientists defend that the region was shaped as a result of northward subduction of an age-old oceanic lithosphere that is Paleotethys pending the Paleozoic-Mesozoic period (e.g., Rice et al., 2009; Dilek et al., 2010). On the other hand, some scientists offer that the region was developed southward subduction of lithospheric plate under the Paleotethys Ocean that was settled down in the north of the mountain zone in course of the Paleozoic to Cenozoic period (Dewey et al., 1973; Bektaş et al., 1999; Eyuboglu, 2010; Eyuboglu et al., 2016). Therefore, it becomes important to investigate the mid-Black arc region with different techniques. There are many scientific studies, that use the gravity data, to examine the deep structural and stratigraphic structure of the region (Mindevalli and Mitchell, 1989; Çakır et al., 2000; Çakır and Erduran, 2004; Angus et al., 2006; Barazangi et al.,
2006; Pamukçu et al., 2007 and Maden et al., 2009). Mindevalli and Mitchell (1989) showed the upper mantle and crust velocity structures using seismic velocities and calculated around $40 \mathrm{~km}$ crustal thickness under the region. Çakır et al. (2000) has calculated that the depth of the Moho ranges from 32 to $40 \mathrm{~km}$ in the mountain region. Also, they found that the dips of Moho roughly southwards. Çakır and Erduran (2004) concluded that Moho interface is situated at about $35 \mathrm{~km}$ depth by using seismic velocities on the north of the region. Also, in the same area, Maden et al. (2009) analyzed the crust structure using gravity values. They calculated the depths of the basement $(4.6 \mathrm{~km})$, Conrad $(26.5 \mathrm{~km})$ and Moho $(35.7 \mathrm{~km})$ using spectral analysis method. Also, using the inversion method, they found the variation of Moho depth from $30.1 \mathrm{~km}$ to 43.8 $\mathrm{km}$ in the region.

Generally, the solution of issues such as the density change limits of the structural and stratigraphic elements forming the earth's crust and the topography of the basement structure can be realized based on the analysis of gravity data. In particular, the Horizontal Gradient (HG) technique is used in determining the discontinuities arising from the difference in density within the earth's crust (Cordell and Grauch, 1985; Nabighian, 1972; Elmas, 2019) and Parker-Oldenburg algorithm (PO) has been used to reveal the basement upper surface topography (Parker, 1973; Oldenburg, 1974; Gomez-Ortiz and Agarwal, 2005; Oruç et al., 2013; Elmas, 2019). In addition, the Tilt Angle (TI) technique is used to reveal the geological structure boundaries (Miller and Singh, 1994; Oruç and Keskinsezer, 2008; Oruç, 2010; Akın et al., 2011; Dogru et al., 2017; Elmas, 2018).

In this study, the structural and stratigraphic characteristics of the region and its vicinity 
were investigated based on the combined and sequential analysis of gravity data using HG, TI and PO techniques. The study area is in the north of Turkey (Figure 1). Earthquake data were obtained from the International Seismological Center (ISC) (Figure 2). The gravity data used in this study were taken from the Earth Gravity Model (EGM08) (Figures 3a). Also, the topography data shown in Figure $3 \mathrm{~b}$ were also taken from the Global 30 Arc-Second Elevation Model (GTOPO30) (USGS, 1998). The mean depths of the interfaces in sediment, basement upper surface, Conrad and Moho interfaces in the region were calculated by the amplitude spectrum of Bouguer gravity data. Gravity values originating from different levels were calculated by applying a band pass filter to Bouguer gravity values. To determine discontinuities, POTENSOFT software (Arisoy and Dikmen, 2011) was used for HG and TI boundary analysis. By applying the HG and TI technique to the first vertical derivative values of the filtered gravity data, the boundaries of the region presenting the density difference in the basement levels were tried to be displayed. Boundary analyzes were made especially for the basement. In addition, the interface topographies in the study area were calculated with the Parker-Oldenburg inverse algorithm.

\section{MATERIALS AND METHODS}

There are some lineaments in the area and particularly we focused on the lineaments of the geological structures (Figure 1).

In the previous studies, the fault type structures of the study area were studied by using different method (Dewey et al., 1973; Bektaş et al., 1999; Eyuboglu et al., 2007; Eyuboglu, 2010; Eyuboglu et al., 2016), but they could not determine boundaries that offered the difference in density for the sub-units. In this study, it was tried to determine the boundaries of subunits which could not be determined by previous studies. HG and TI techniques were used for this purpose.

Parker-Oldenburg algorithm has been used nowadays to reveal the topographies of the interface in the crust (Elmas, 2019). Gomez-Ortiz and Agarwal (2005) developed the 3DINVER inversion program. In addition, POTENSOFT program prepared by Arisoy and Dikmen (2011) was used to determine the boundaries that arise from the density differences. Figure 2 presents the epicentes of earthquakes with magnitude greater than 3 from 1996 to 2020 (URL-1, 2020). Looking at the figure, many earthquakes are observed around the fault zones. In addition, if the hypocenter depths of earthquakes are examined, it can be seen that most earthquakes are at the first $10 \mathrm{~km}$ depth. The Bouguer gravity values seen in Figure 3a were obtained from Earth Gravity Model (EGM08) (Pavlis et al., 2008). When gravity anomaly is examined, the location of the main fault zones can be seen approximately. Also the gravity anomaly increased to the north. The gravity values in the study area go up from south to north. This causes crust thickness to decrease from south to north. In other words, with the thinning of the crust, the gravity values increased from south to north with the geological structure of astenosphere with a high density approaching upward. The topography values shown in Figure $3 \mathrm{~b}$ were compiled from Global 30 Arc-Second Elevation Model (GTOPO30) (USGS, 1998). In contrast to gravity data, topography values decrease from south to north. When the gravity and topography data are taken together, NAFZ location can be seen. 
Parlak, Elmas

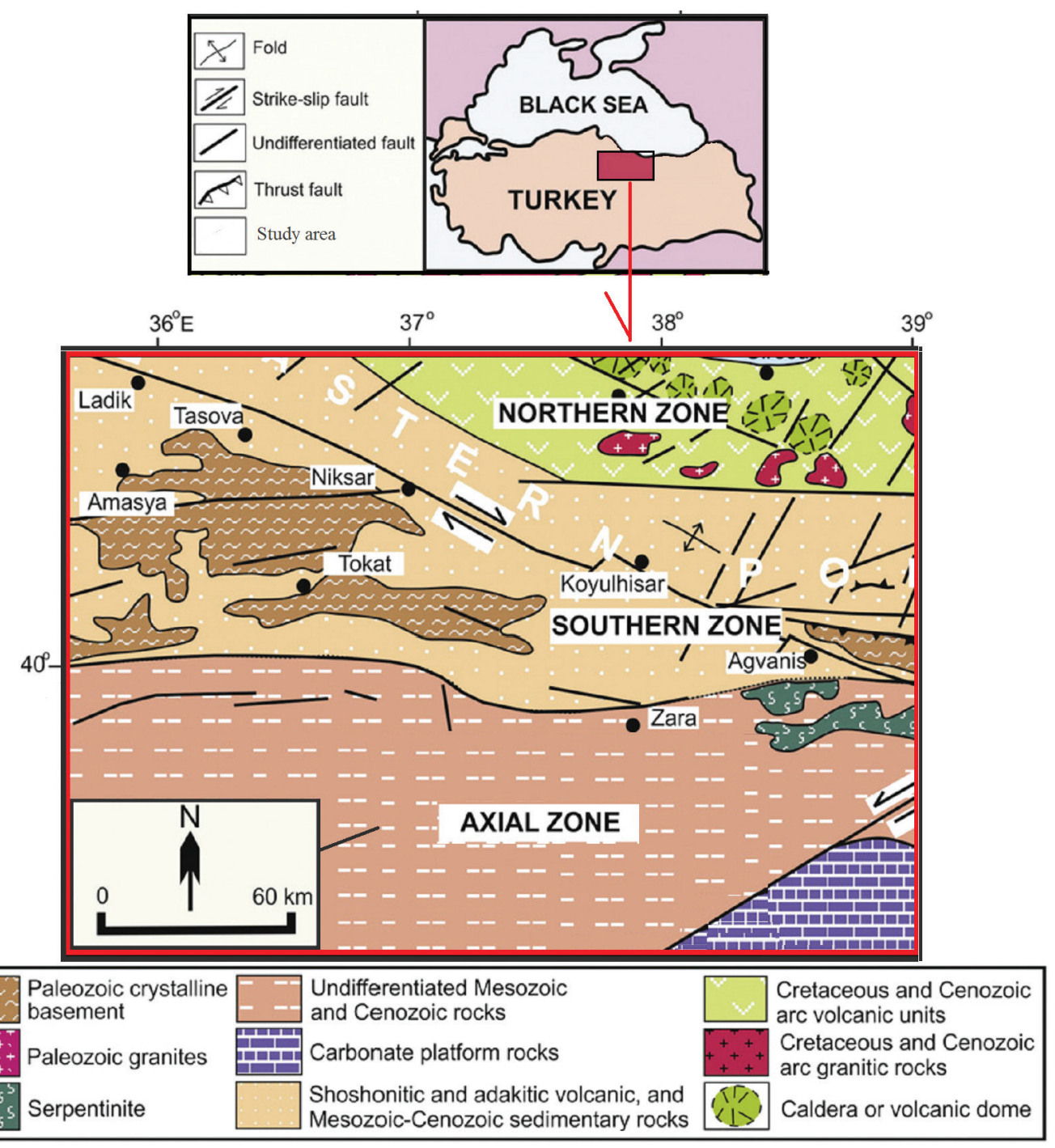

Figure 1. Map of the geological and tectonic structures of the region (After Eyuboglu et al., 2007). Northern zone, southern zone and axial zone are seen. The main discontinuity boundaries separating these zones are also seen here. Şekil 1. Bölgenin jeolojik ve tektonik yapı haritası (Eyuboglu vd. 2007'den düzenlenmiştir). Kuzey zonu, güney zonu ve eksen zonu görülmektedir. Bu zonları ayıran ana süreksizlik sinırları da burada görülmektedir.

\section{CALCULATION OF THE DEPTH OF THE INTERFACES}

The amplitude spectrum calculated from the Fourier transforms of potential field anomalies provide information about the mean depths of the interface boundaries (Bhattacharya, 1967;
Spector and Grant, 1970). The amplitude spectrum is written as in Equation (1), where $\mathrm{F}(\mathrm{x})$ is the potential data measured on the earth plane.

$$
A(w)=\sum_{0}^{n-1} F(x) e^{-i w x}
$$




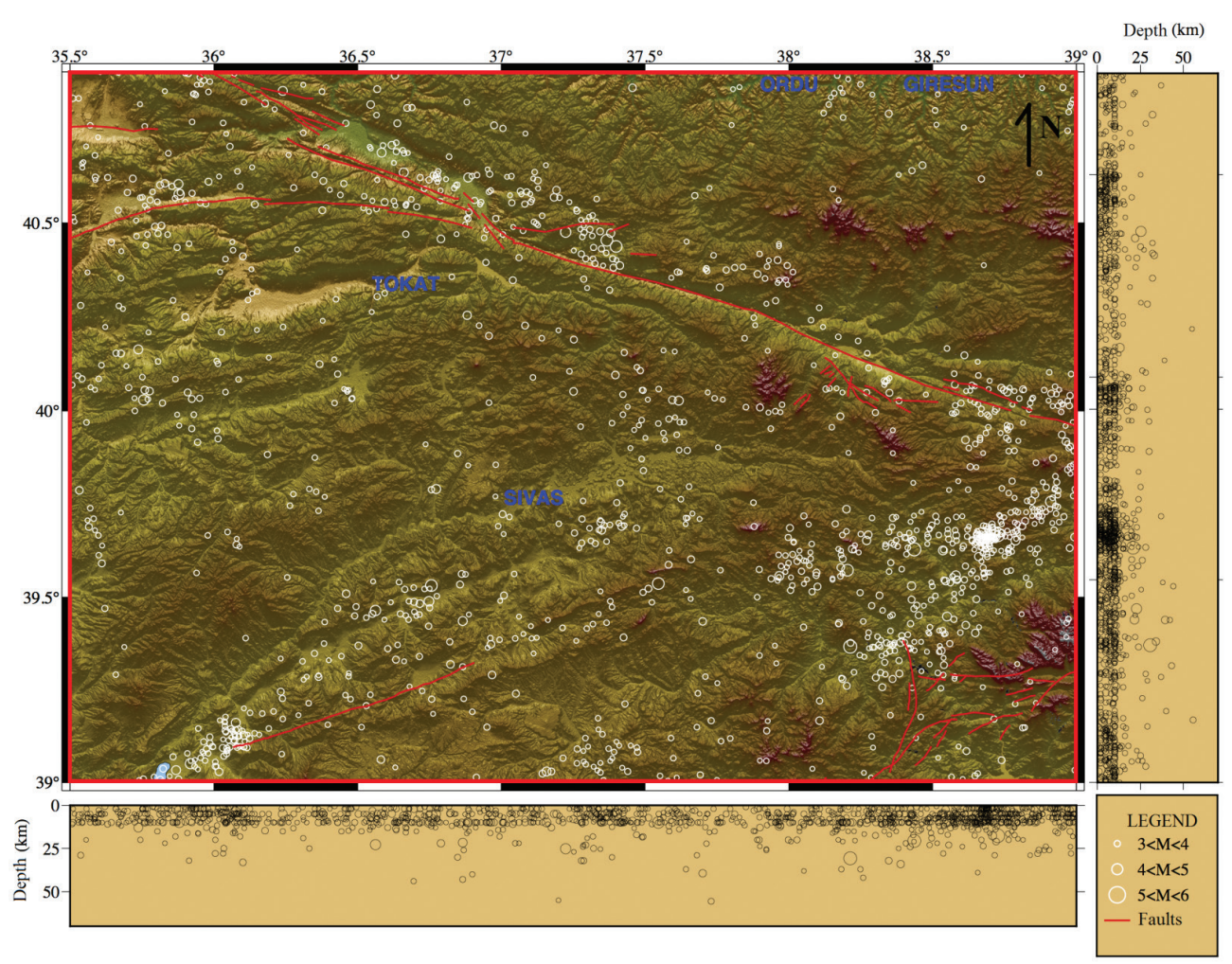

Figure 2. Epicenter and hypocenter of earthquakes for the study region (ISC). (Active faults taken from Emre et al., 2013).

Şekil 2. Çalışma bölgesi için depremlerin merkez üssü ve odak derinlikleri (ISC). (Aktif faylar, Emre vd., 2013'den alınmıştır).

In Equation (1), $\mathrm{w}=2 \pi \mathrm{k}$ is defined as the angular frequency and $\mathrm{k}$ is defined as $\mathrm{k}=1 / \lambda$ as the inverse of the wavelength $(\lambda)$. The Fourier spectrum of the interface boundary or Bouguer plate effect at the mean depth $\mathrm{h}$ is given by Karner and Watts (1983) as in Equation (2).

$$
B(k)=2 \pi G \Delta \rho e^{-2 \pi k h} F(k)
$$

In Equation (2), $\Delta \rho$ is the density difference between the two layers bounding the plate, $G$ is the universal gravity constant, and $\mathrm{F}(\mathrm{k})$ is the Fourier spectrum of the measured data. It is clear from Equation (2) that the only factor affecting the characteristic variation of the amplitude spectrum is the exponential term. Equation (3) is obtained by taking the natural logarithm of both sides.

$$
\operatorname{In} B(k)=\operatorname{In} A(k) \pm 2 \pi k h
$$

Thus, it is clear that a linear relationship will be found if the logarithmic amplitude spectrum is plotted against the wavenumber. The parameter affecting the slope of the line is the average depth $h$ of the interface boundary. By utilizing this property, the average depths of the interface boundaries can be found. With this technique, 2D Fourier transformation of the gravity data is calculated. With this process, four different interface depths were calculated (Figure 4). With the spectrum process, calculated average depths 
Parlak, Elmas

of the interfaces are $39.2 \mathrm{~km}, 11.4 \mathrm{~km}, 5.1 \mathrm{~km}$, and $2.1 \mathrm{~km}$. These are belong to Moho, conrad, basement, and hard-soft sediment interfaces, respectively. In this study, the algorithm developed by Parker (1973) and Oldenburg (1974) was used to calculate the interface topographies (Figure 5). The inversion processes are made with this algorithm. In the inversion processes performed in this study, if the Root Mean Square (RMS) error obtained from two consecutive results is lower than the specified $0.01 \mathrm{~km}$, convergence criterion, the iteration process ends. The used algorithm is described in detail in Elmas (2019).
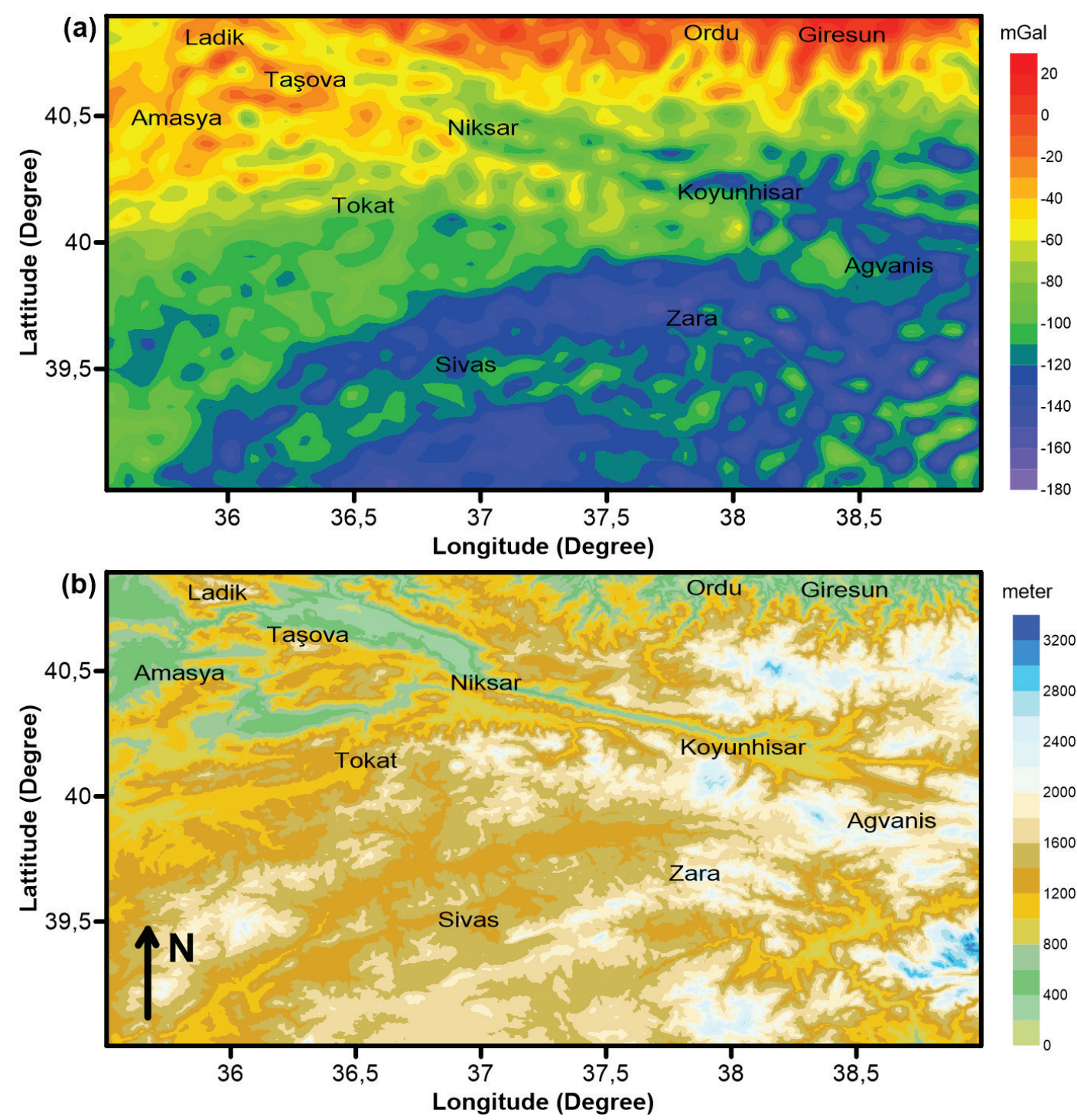

Figure 3. (a) EGM08 Bouguer gravity values, (b) topographic maps of the region.

Şekil 3. Bölgenin (a) EGM08 Bouguer gravite değerleri, (b) topografya haritalart. 


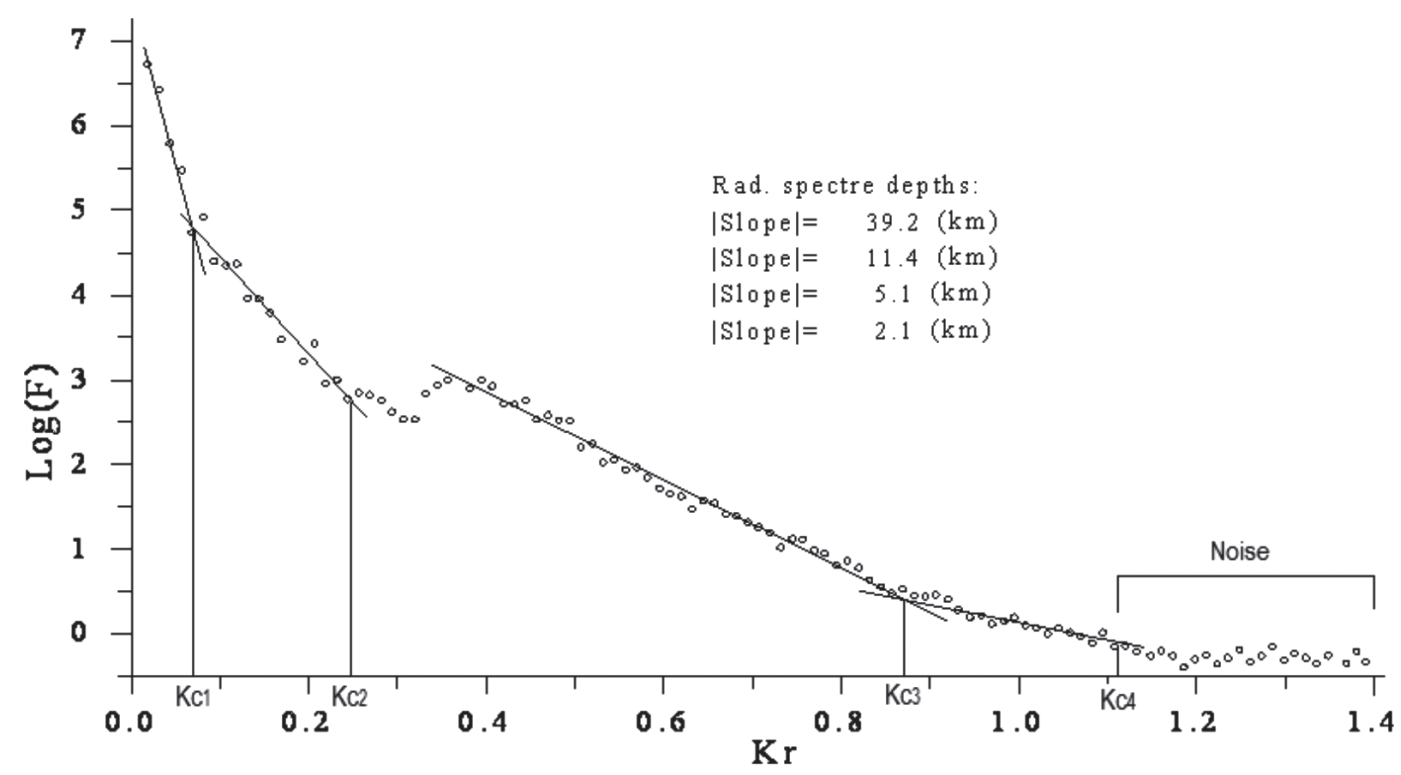

Figure 4. Amplitude spectrum of the gravity data for the study region.

Şekil 4. Çalışma bölgesi için gravite verilerinin genlik spektrumu.

\section{LINEAMENT DETECTION}

HG technique was used with gravity values (Altınoğlu et al., 2015). Here, these techniques were used with FVD data. Oruç (2010) was the first to use the TI technique with FVD data in order to find the lineaments due to the density difference. In this study, the above-mentioned techniques were applied to FVD data and lineaments were determined. First of all, filtered data was calculated from Bouguer data with band pass filter using and. The FVD data was then calculated from the filtered data with fast Fourier transform (FFT). The lineaments found using this technique correspond to the boundaries and fault lines of the masses presenting the density difference.

Cordell and Grauch (1985) were the first to introduce the HG technique, which revealed shallow structure boundaries and the formula is written for first vertical derivative data as (Oruç, 2010)
$H(x, y)=\sqrt{\left(\frac{\partial^{2} g}{\partial x \partial z}\right)^{2}+\left(\frac{\partial^{2} g}{\partial y \partial z}\right)^{2}}$

where $\frac{\partial^{2} \mathrm{~g}}{\partial \mathrm{x} \partial \mathrm{z}}$ and $\frac{\partial^{2} \mathrm{~g}}{\partial \mathrm{y} \partial \mathrm{z}}$ are FVD of regional gravity values changes in $\mathrm{x}$ - and $\mathrm{y}$ - directions. In Equation (4), horizontal derivatives are calculated using finite differences.

Miller and Singh (1994) were the first to introduce the TI technique, which revealed both shallow and deep structure boundaries. The formula of this technique can be written according to FVD data as

$$
\varphi=\tan ^{-1}\left(\frac{\frac{\partial^{2} \mathrm{~g}}{\partial \mathrm{z}^{2}}}{\sqrt{\left(\frac{\partial^{2} \mathrm{~g}}{\partial \mathrm{x} \partial \mathrm{z}}\right)^{2}+\left(\frac{\partial^{2} \mathrm{~g}}{\partial \mathrm{y} \partial \mathrm{z}}\right)^{2}}}\right)
$$

where $\varphi$ represents the TI degree (Oruç 2010). 
On the other hand, the Parker-Oldenburg inversion algorithm was used to model the interface topographies using the average depth values found by the amplitude spectrum technique. This algorithm is depended on the connection between the Fourier transform of the interface topography and the Fourier transform of the gravity values. Therefore, this connection is recursively formed from the density difference and determined depth of an interface of geological structure (Parker 1973; Oldenburg 1974). The Fourier transform utilized to compute gravity values of an irregular homogeneous layer is as follows:

$f\left[z_{1}(x)\right]=-\frac{f[\Delta g(x)] e^{|k| z_{0}}}{2 \pi G \rho}-\sum_{n=2}^{\infty} \frac{|k|^{n-1}}{n !} f\left[z_{1}^{n}(x)\right]$,

where $f[\Delta g(x)], z_{0}, z_{1}(x), k, G$, and $\rho$ are the Fourier transform of the gravity values, average depth, depth under each measurement point, wavenumber, gravitational constant, and the difference of the densities above and below the boundary, respectively. Equation (6) is utilized to compute density interface iteratively utilizing $\mathrm{z}_{0}$ and $\Delta g(\mathrm{x})$. The first prediction the depth of interface is ensured by inverse Fourier transform. Also, this interface value can be utilized to find the right of Equation (6). For this reason, this cause to be finalizing the second depth reaches findings. When the convergence criterion is reached, iterations are terminated.

\section{RESULTS}

Average depths of interfaces found by applying Bouguer gravity values of region to amplitude spectrum are 2.1, 5.1, 11.4, and $39.2 \mathrm{~km}$ (Figure 4). These depth values belong to soft-hard sediment, basement, Corad and Moho interfaces, respectively. Finding the interface topographies especially of basement are important to outline the geological units of the region. In respect to geophysical data from the area, we found depth of basement of this region is $4.6 \mathrm{~km}$ on previous study (Maden, 2013). Earthquakes usually occur at these depths in this region and it is understood that there is a consistency between depth and seismicity for the depth of basement. The low pass filter was used to obtain filtered gravity anomalies for Moho using Kc1 cut-off wave number. The band pass filter was used to obtain filtered gravity anomalies for conrad using Kc1-Kc2 cut-off wave numbers, for basement using Kc2-Kc3 cut-off wave numbers, and for soft-hard sediment using Kc3-Kc4 cutoff wave numbers for inversion processes. The filtered gravity anomalies are originated from the soft-hard sediment, basement, Conrad and Moho interfaces and are given in Figures 5a, 5c, $5 \mathrm{e}$, and $5 \mathrm{~g}$, respectively. Looking at the gravity anomaly maps, it can be seen that the wavelength increases from top to bottom.

The inverse solution is made by considering the soft-hard sediment, basement, Conrad, and Moho interfaces. It was used with the 3DINVER and 3D geometries of soft-hard sediment, basement, Conrad, and Moho were iteratively estimated. As initial depths, 2.1, 5.1, 11.4, and $39.2 \mathrm{~km}$ are used to derive the interface topographies for soft-hard sediment, basement, Conrad and Moho, respecticely. Average density contrasts have been selected as $0.1 \mathrm{~g} / \mathrm{cm}^{3}$ for soft-hard sediment (accepted densities of hard sediment and soft sediment are $2.4 \mathrm{~g} / \mathrm{cm}^{3}$ and $2.3 \mathrm{~g} / \mathrm{cm}^{3}$, respectively), $0.3 \mathrm{~g} / \mathrm{cm}^{3}$ for basement (accepted densities of metamorphic complex and sediment are $2.7 \mathrm{~g} / \mathrm{cm}^{3}$ and $2.4 \mathrm{~g} / \mathrm{cm}^{3}$, respectively), $2.26 \mathrm{~g} / \mathrm{cm}^{3}$ for Conrad (accepted densities of lower crust and upper crust are 2.93 $\mathrm{g} / \mathrm{cm}^{3}$ and $2.67 \mathrm{~g} / \mathrm{cm}^{3}$, respectively), and $0.5 \mathrm{~g} /$ $\mathrm{cm}^{3}$ for Moho (accepted densities of lithospheric mantle and crust are $3.3 \mathrm{~g} / \mathrm{cm}^{3}$ and $2.8 \mathrm{~g} / \mathrm{cm}^{3}$, respectively). 

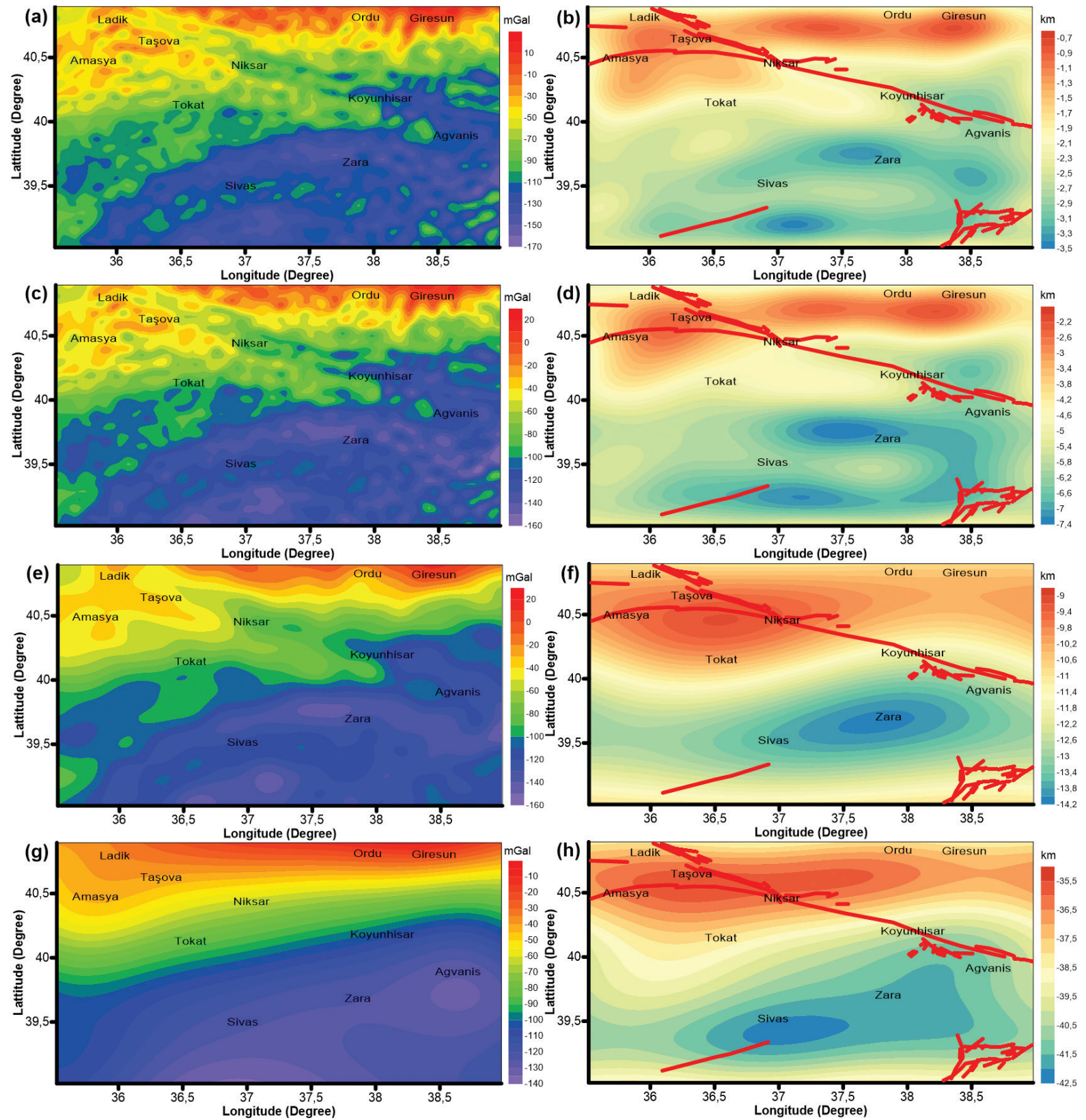

Figure 5. (a) The gravity anomaly map from soft-hard sediment topography, (b) the soft-hard sediment topography map, (c) the gravity anomaly map from basement topography, (d) the basement topography map, (e) the gravity anomaly map from Conrad topography, (f) the Conrad topography map, (g) the gravity anomaly map from Moho topography, (h) the Moho topography map. Known faults are given in red.

Şekil 5. (a) Yumuşak-sert sediment topografyasından gravite anomali haritası, (b) yumuşak-sert sediment topografya haritasl, (c) temel kaya topografyasından gravite anomali haritasl, (d) temel kaya topografya haritası, (e) Conrad topografyasindan gravite anomali haritast, (f) Conrad topografya haritast, (g) Moho topografyasindan gravite anomali haritası, (h) Moho topografya haritası. Bilinen faylar kırmızı renkte verilmiştir. 
Parlak, Elmas

The iteration numbers, and RMS errors are also determined for each inversion. The obtained topography maps, given in Figures $5 \mathrm{~b}, 5 \mathrm{~d}, 5 \mathrm{f}$, and $5 \mathrm{~h}$, show that Bouguer data are correlated with the interface topographies. Here, looking at the interface topography maps, the corrugation structure at the borders can be seen from bottom to top. Since the boundaries between descents and elevations of basement are related to lineaments such as faults (Oruç et al. 2013), the found lineaments can be associated with the basement topography. Depth values for soft-hard sediment, basement, Conrad and Moho interface topographies are changed as 0.7-3.5, 2.1-7.4, 9.114.2 , and $35.1-42.5 \mathrm{~km}$, respectively. In addition to tracking the descending and ascending portions of the interfaces, it is seen that the crust in the working area is thinned from the south to the north by looking at the interface depth values (Figures 5b, 5d, 5f, and 5h). In addition, if we look at the gravity maps and the interface topography maps which are calculated with the inverse solution together, NAFZ may be visually recognized in sediment and basement, especially on the first two gravity map.

The maximum $\mathrm{HG}$ values and zero TI values reflect the geological structure boundaries that present the density differences. Some of these boundaries are in line with ICS. From this point of view, it can be said that some of the found lineaments are known faults. The regional gravity anomaly and the FVD of regional gravity of region are given in Figure $6 \mathrm{a}$ and $6 \mathrm{~b}$. When the gravity and FVD maps are considered, especially NAFZ can be seen. Again, this fault can be clearly seen on HG and TI maps. In addition, when we look at the HG and TI maps, we can clearly see the distribution of the geological structure boundaries offering density differences that are dominant in the region and at the basement levels.
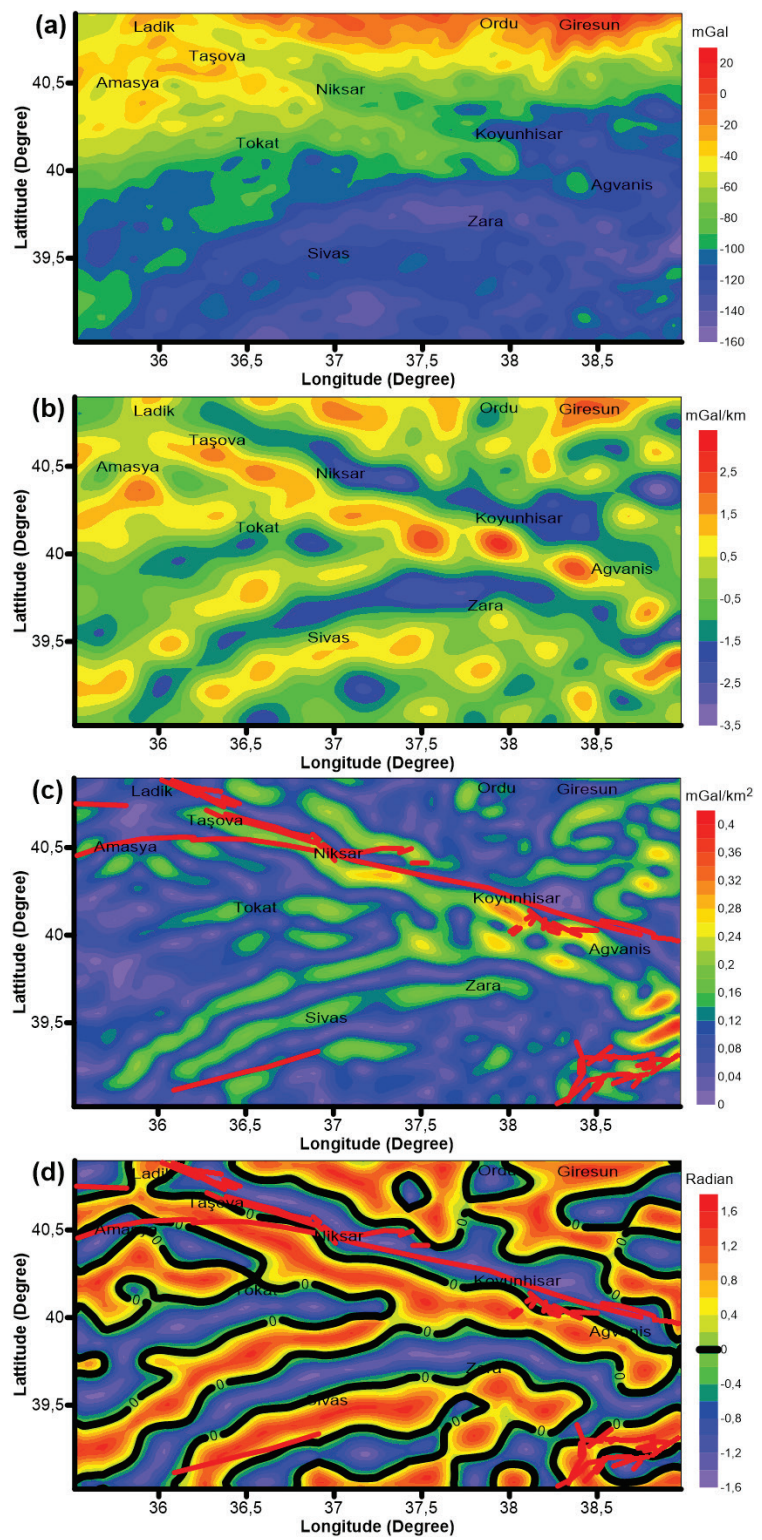

Figure 6. (a) Regional data, (b) FVD data, (c) HG map, (d) TI map. Known faults are plotted in red.

Şekil 6. (a) Bölgesel veriler, (b) FVD verileri, (c) $H G$ haritası, (d) TI haritası. Bilinen faylar kırmızı ile işaretlenmişstir.

The high $\mathrm{HG}$ values that are lineaments display mainly E-W, NE-SW, and NW-SE displacive units shown in Figure 6c. We found the zero values of the TI in the lineaments, shown 
in Figure 6d. The zero values of TI map displays mainly $\mathrm{W}-\mathrm{E}, \mathrm{SW}-\mathrm{NE}$, and SE-NW displacive tectonic discontinuities shown in Figure 6d. Looking at the results of $\mathrm{HG}$ and TI, it is seen that $\mathrm{HG}$ gives shallow lineaments, while TI gives both shallow and deep lineaments (Figures 6c and 6d). NAFZ is clearly visible, as well as the positions and extensions of other linearities (Figures $6 \mathrm{c}$ and $6 \mathrm{~d}$ ). Distributions of the ore deposits (Figures 7a and 7b) and the epicenter of the earthquake (Figure 7c) in the region support the existing of the newly found lineaments. Since the ore deposits are related to the fault systems, the distribution of the ore deposits in the region and the distribution of the faults have been evaluated together. In addition, earthquake epicenter distributions were also taken into account in this regard. The ore deposits map was obtained off General Directorate of Minerals Research and Exploration (MTA) of Turkey (URL-2, 2020). The known faults are given in red in Figure $7 \mathrm{~d}$. Also, found lineaments given by dotted lines are shown in black in Figure $7 d$. The distribution comparison between ore deposits, epicenters of the earthquake, faults and lineaments in Figure 7 was made qualitatively.

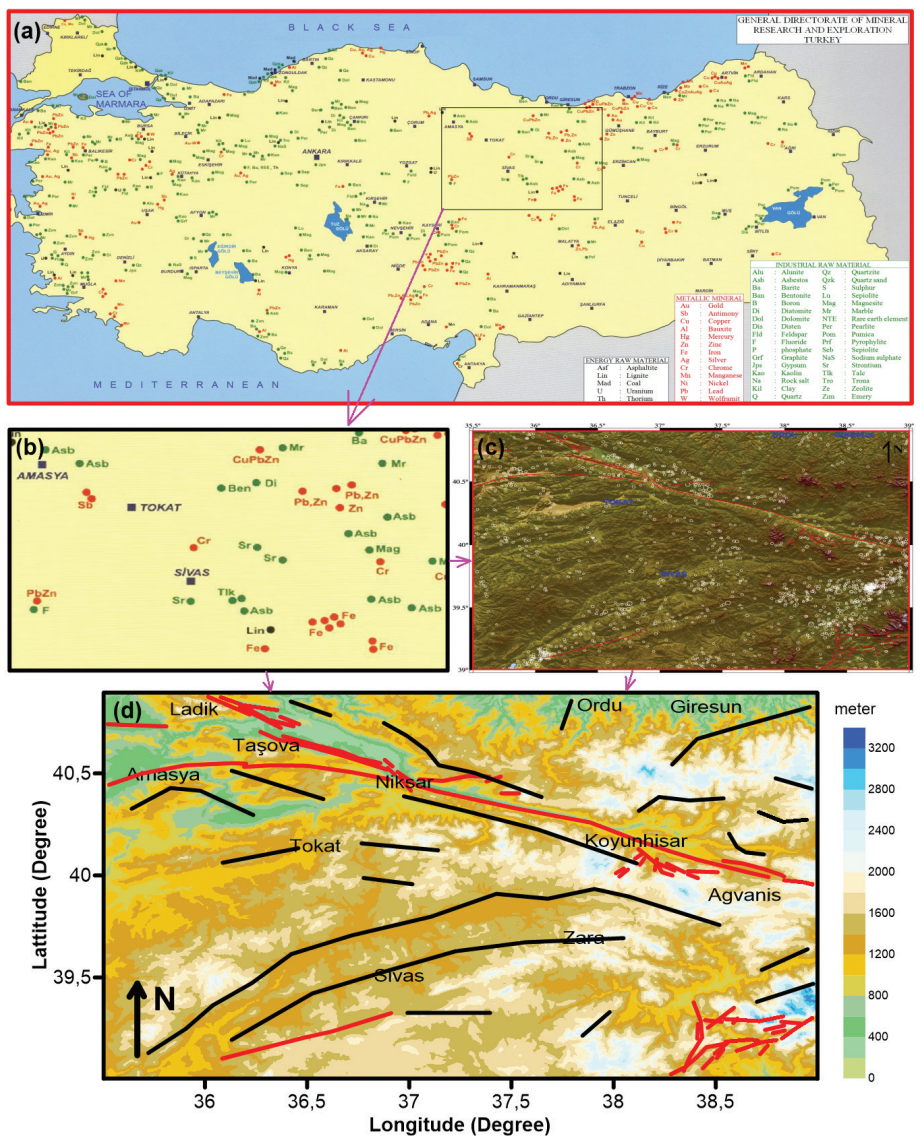

Figure 7. (a) Turkey ore deposits map (URL-2, 2020), (b) ore deposits map of study area, (c) seismicity of the region, (d) known faults have been compiled from ISC (in red) and found lineaments (in black).

Şekil 7. (a) Türkiye maden yatakları haritası (URL-2, 2020), (b) çalışma alanının maden yatakları haritası, (c) bölgenin depremselliği, (d) bilinen faylar ISC'den derlenmiş (kırmızı) ve bulunan çizgisellikler ( siyah). 


\section{CONCLUSIONS}

In this study, by using the maximum $\mathrm{HG}$ and zero TI values, lineaments belonging to the region and resulting from density differences were found. The lineaments found are compared with the interface topographies. The main lineaments found in this study are compatible with theworks that made by Dewey et al. (1973), Bektaş et al. (1999), Eyüboğlu et al. (2007), Eyuboglu (2010), Eyuboglu et al. (2016). Here, we determined descents and elevations in the interface topography maps (Figures $5 \mathrm{~b}, 5 \mathrm{~d}, 5 \mathrm{f}$ and 5e). It is remarked by Dewey et al. (1973), Bektaş et al. (1999), Eyüboğlu et al. (2007), Eyuboglu (2010), Eyuboglu et al. (2016) that there is no lineament about subunits detected by previous studies in this region, except that we have newly found some lineaments (Figure 10d).

The study area is important in terms of ore deposits. On the other hand, the region has experienced many eartquakes since ancient times and faces severe seismic threats. In this study, Moho, Conrad, basement and soft-hard sediment interface topographies were found with inversion. Interface depth values were examined and it was seen that the crust thickness in the study area decreased from south to north (Figures $5 \mathrm{~b}, 5 \mathrm{~d}, 5 \mathrm{f}$ and $5 \mathrm{e}$ ). In addition, as a result of inversion processes, the descents and elevations areas in the interface topographies are revealed. Geological and geophysical studies to be carried out in the region can be directed by considering the location of the ore deposits in the study area, the location of the epicenters and the locations of the geological structure boundaries found. If the results of this study are supported by more detailed studies, it will be easier to identify the ore deposits that are present in the study area, but have not yet been discovered and places where the earthquake risk is high. Because, these are connected to fracture and fault systems.

\section{REFERENCES}

Akın, U., Şerifoğlu, B.İ., Duru, M., 2011. The use of tilt angle in gravity and magnetic methods. Maden Tetkik ve Arama Dergisi, 143(143), 1-12.

Altınoğlu, F.F., Sarı, M., Aydın, A., 2015. Detection of Lineaments in Denizli Basin of Western Anatolia Region Using Bouguer Gravity Data. Pure and Applied Geophysics, 172, 415-425.

Angus, D.A., David, C., Wilson, E., Sandvol, E., 2006. Lithospheric structure of the Arabian and Eurasian collision zone in eastern Turkey from S-wave receiver functions. Geophysical Journal International, 166, 1335-1346.

Arısoy, M.Ö., and Dikmen, Ü., 2011. Potensoft: MATLAB-based Software for potential field data processing, modelling and mapping. Computer and Geosciences, 37, 935-942.

Barazangi, M., Sandvol, E., Seber, D., 2006. Structure and tectonic evolution of the Anatolian plateau in eastern Turkey. In: Dilek, Y., Pavlides, S. (Eds.), Post-collisional Tectonics and Magmatism in the Mediterranean Region and Asia. Geological Society of America Bulletin, 409, 463-474.

Bektaş, O., Şen, C., Atıcı, Y., Köprübaşı, N., 1999. Migration of the Upper Cretaceous subductionrelated volcanism toward the back-arc basin of the eastern Pontide magmatic arc (NE Turkey). Geological Journal, 34, 95-106.

Bhattacharyya, B.K., 1967. Some general properties of potential fields in space and frequency domain; a review. Geoexploration, 5, 127-143.

Cordell, L., Grauch, V.J.S., 1985. Mapping basement magnetization zones from aeromagnetic data in the San Juan Basin, New Mexico, (Ed. Hinze, W. J.) The utility of regional gravity and magnetic anomaly maps. Society of Exploration Geophysicists, 181-197.

Çakır, Ö., Erduran, M., Çınar, H., Yılmaztürk, A., 2000. Forward modeling receiver functions for crustal structure beneath station TBZ (Trabzon, Turkey). Geophysical Journal International, 140, 341-356. 
Çakır, Ö., Erduran, M., 2004. Constraining crustal and uppermost structure beneath station TBZ (Trabzon, Turkey) by receiver function and dispersion analyses. Geophysical Journal International, 158, 955-971.

Dilek, Y., Imamverdiyev, N., Altunkaynak, Ş., 2010. Geochemistry and tectonics of Cenozoic volcanism in the Lesser Caucasus (Azerbaijan) and the peri-Arabian region: collision-induced mantle dynamics and its magmatic fingerprint. International Geology Review, 52 (4-6), 536578.

Dewey, J.F., Pitman, W.C., Ryan, W.B.F., Bonnin, J., 1973. Plate tectonics and evolution of the Alpine system. Geological Society of America Bulletin, 84, 3137-3180.

Dogru, F., Pamukcu, O., Ozsoz, I., 2017. Application of tilt angle method to the Bouguer gravity data of Western Anatolia. Maden Tetkik ve Arama Dergisi, 155(155), 213-222.

Elmas, A., 2018. Kibris adasındaki yapisal süreksizliklerin EGM08 gravite verileri kullanılarak belirlenmesi. Jeoloji Mühendisliği Dergisi, 42, 17-32.

Elmas, A., 2019. Edge position detection and depth estimation from gravity data with application to mineral exploration. Carbonates and Evaporites, 34 (1), 189-196.

Emre, Ö., Duman, T.Y., Özalp, S., Elmacı, H., Olgun, Ş., Şaroğlu, F., 2013. Açıklamalı 1/1.250.000 Ölçekli Türkiye Diri Fay Haritası, Maden Tetkik ve Arama Genel Müdürlüğü, Özel Yayın Serisi-30. Ankara- Türkiye.

Eyuboglu, Y., Bektaş, O., Pul, D., 2007. MidCretaceous olistostromal ophiolitic melange developed in the back-arc basin of the eastern Pontide magmatic arc (NE Turkey). International Geology Review, 49 (12), 1103-1126.

Eyuboglu, Y., Dudas, F.O, Santosh, M., Zhu, D.C., Yi, K., Chatterjee, N., Akaryali, E., Liu, Z., 2016. Cenozoic forearc gabbros from the northern zone of the Eastern Pontides Orogenic Belt, NE Turkey: Implications for slab window magmatism and convergent margin tectonics. Gondwana Research, 33, 160-190.
Eyuboglu, Y., Santosh, M., Dudas, F.O., Chung, S.L., Akaryali, E., 2011. Migrating magmatism in a continental arc: Geodynamics of the Eastern Mediterranean revisited. Journal of Geodynamics, 52, 2-15.

Eyuboglu, Y., 2010. Late Cretaceous high-K volcanism in the eastern Pontides orogenic belt, and its implications for the geodynamic evolution of NE Turkey. International Geology Review, 52 (2-3), 142-186.

Gomez-Ortiz, D., Agarwal, B.N.P., 2005. 3DINVER. M: A MATLAB program to invert the gravity anomaly over a 3-D horizontal density interface by Parker-Oldenburg's algorithm. Computer Geosciences, 31, 513-520.

Karner, G. D., Watts, A. B., 1983. Gravity anomalies and flexure of the lithosphere at mountain ranges. Journal of Geophysical Research: Solid Earth, 88(B12), 10449-10477.

Maden, N., Gelişli, K., Bektaş, O., Eyuboglu, Y., 2009. Two-and-three-dimensional crust topography of the Eastern Pontides (NE Turkey). Turkish Journal of Earth Sciences, 18, 225-238.

Maden, N., 2013. Geothermal structure of the eastern Black Sea basin and the eastern Pontides orogenic belt: Implications for subduction polarity of Tethys oceanic lithosphere. Geoscience Frontiers, 4, 389-398.

Miller, H.G., Singh, V., 1994. Potential field tilt -a new concept for location of potential field sources. Journal of Applied Geophysics, 32, 213-217.

Mindevalli, Ö.Y., Mitchell, B.J., 1989. Crustal structure and possible anisotropy in Turkey from seismic surface wave dispersion. Geophysical Journal International, 98, 93-106.

Nabighian, M.N., 1972. The analytic signal of two dimensional magnetic bodies with polygonal cross section: Its properties and use for automated anomaly interpretation. Geophysics, 37, 507-517.

Oldenburg, D.W., 1974. The inversion and interpretation of gravity anomalies. Geophysics, 39, 526-536. 
Parlak, Elmas

Oruç, B., Keskinsezer, A., 2007. Normalize tam Gradyent Yöntemi ile petrol sahalarındaki Manyetik Temel Kaya Ondülasyonunun Modellenmesi, IPETGAS.

Oruç, B., Sertçelik, İ., Kafadar, Ö., Selim, H.H., 2013. Structural interpretation of the Erzurum Basin, Eastern Turkey, using curvature gravity gradient tensor and gravity inversion of basement relief. Journal of Applied Geophysics, 88,105-113.

Oruç, B., 2010. Edge detection and depth estimation using a tilt angle map from gravity gradient data of the Kozakl1-Central Anatolia Region, Turkey. Pure and Applied Geophysics, 168.10, 17691780 .

Pamukçu, O.A., Akçı̆̆g, Z., Demirbaş, Ş., Zor, E., 2007. Investigation of crustal thickness in eastern Anatolia using gravity, magnetic and topographic data. Pure and Applied Geophysics, 164, 2345-2358.

Parker, R.L., 1973. The rapid calculation of potential anomalies. Geophysical Journal of the Royal Astronomical Society, 31, 447-455.
Pavlis, N.K., Holmes, S.A., Kenyon, S.C., Factor. J.K., 2008. An Earth Gravitational Model to Degree 2160: EGM2008. EGU General Assembly 2008, Vienna, Austria, April 13-18, 2008. http:/earth-info.nga.mil/GandG/wgs84/ gravitymod/egm2008, (Accessed 8 Aug 2020).

Rice, S.P., Roberson, A.H.F., Ustaömer, T., İnan, T., Tasl1, K., 2009. Late Cretaceous-Early Eocene tectonic development of the Tethyan Suture Zone in the Erzincan area, eastern Pontides, Turkey. Geological Magazine, 146 (4), 567-590.

Spector, A., Grant F.S., 1970. Statistical models for interpreting aeromagnetic data. Geophysics, 35, 293-302.

URL-1，2020. http://www.isc.ac.uk/iscbulletin/. (Accessed 8 Aug 2020).

URL-2, 2020. http://www.mta.gov.tr/v3.0/bolgeler/ trabzon. (Accessed 8 Aug 2020).

U.S. Geological Survey, Digital Elevation Models GTOPO30, Virginia, 1998. http://webmap.ornl. gov/wcsdown/wcsdown.jsp?dg_id=10003_1, (Accessed 8 Aug 2020). 